Author Accepted Manuscript. Published in Waste Management and Research DOI: 10.1177/0734242X16649680

\title{
Greenhouse gas emissions of waste management processes and options: A case study
}

\author{
Belen de la Barrera1,2 and Peter S. Hooda ${ }^{1 *}$ \\ ${ }^{1}$ Kingston University London \\ School of Natural and Built Environments \\ Kingston upon Thames, Surrey KT1 EE, United Kingdom \\ 2Present address: Duke University Wetland Center, Nicholas School of the \\ Environment, Durham, NC 27708, USA (bid2@duke.edu)
}

*Corresponding author (PS Hooda): P.Hooda@Kingston.ac.uk 


\begin{abstract}
Increasing concern about climate change is prompting organisations to mitigate their greenhouse gas (GHG) emissions. Waste management activities also contribute to GHG emissions. In the waste management sector, there has been an increasing diversion of waste sent to landfill, with much emphasis on recycling and reuse to prevent emissions. This study evaluates the carbon footprint of the different processes involved in waste management systems, considering the entire waste management stream. Waste management data from the Royal Borough of Kingston upon Thames (RBK), London (UK), was used to estimate the carbon footprint for its (RBK) current source segregation system. Secondly, modelled full and partial co-mingling scenarios were used to estimate carbon emissions from these proposed waste management approaches. The GHG emissions from the entire waste management system at RBK were 12,347 tonnes $\mathrm{CO}_{2} \mathrm{e}$ for the source segregated (SS) scenario, and 11,907 tonnes $\mathrm{CO}_{2} \mathrm{e}$ for the partial comingled (PC) model. These emissions amount to $203.26 \mathrm{~kg} \mathrm{CO}_{2} \mathrm{e} /$ tonne and $196.02 \mathrm{~kg}$ $\mathrm{CO}_{2} \mathrm{e} /$ tonne MSW for SS and PC, respectively. The change from a source segregation fleet to a partial co-mingling fleet reduced the emissions, at least partly due to a change in the number and type of vehicles.
\end{abstract}

Key words: GHG, waste management, carbon footprint, source-segregation, partial comingling, full co-mingling, waste transportation, waste treatments

\title{
1. Introduction
}

Waste production increases with wealth, urbanisation and population. Globally, 1.3 billion tonnes of municipal solid waste (MSW) were generated in 2011, and it is expected to increase to 2.2 billion tonnes by 2025 (Levis et al., 2013; Vergara and Tchobanoglous, 2012). Waste management activities account for approximately $4 \%$ of the global greenhouse gas emissions (GHG), particularly from the release of methane from organic waste decomposition in landfills (Papageorgiou et al., 2009; Vergara and Tchobanoglous, 2012). It is estimated that in the UK, MSW management produces 175 $\mathrm{kg}$ carbon dioxide equivalents per tonne waste (Mühle et al., 2010). Carbon dioxide equivalents $\left(\mathrm{CO}_{2} \mathrm{e}\right)$ are a measure of the GHG emissions on the basis of their global warming potential. In 2010, the UK generated $521 \mathrm{~kg}$ MSW/year per person; of this, $49 \%$ was land filled, $12 \%$ was incinerated, $25 \%$ was recycled, and $14 \%$ was composted (Eurostat, 2012). For effective MSW management, it is important that the GHG emissions from waste transportation, its treatment and eventual disposal are considered.

Transportation of waste includes all activities where waste is collected and moved from one location to another; these can include transportation from the collection area to the unloading point, transportation between treatments facilities, and transportation to the industries using the materials (Eisted et al., 2009). The waste transportation emissions can be influenced by vehicle type, fuel used, carrying capacity and driving behaviour (Eisted et al., 2009). These GHG emissions are expressed as kg of carbon dioxide equivalents per tonne per kilometre $\left(\mathrm{kg} \mathrm{CO}_{2} \mathrm{e} /\right.$ tonne $\left./ \mathrm{km}\right)$. In MSW management, there are various processes that can collect recyclable and non-recyclable materials; these can be source segregation, full co-mingling and partial co-mingling of the waste. One study found that the co-mingled option collected at most $60 \%$ of the recyclable portion due to inconsistent separation from the waste generators (Levis et al., 2013). On the other hand, source segregation is highly dependent on the proper waste separation at the generators' level and its effective sorting (Vergara and Tchobanoglous, 2012).

The aim of this study was to assess carbon emissions of different waste management operations, particularly the emissions associated with the collection and transportation 
of MSW, using The Royal Borough of Kingston (RBK) as a case study. The specific research objectives were: (a) to estimate the carbon footprint of a source segregated waste collection system, currently in operation in RBK, and (b) to assess the carbon footprint of modelled full and partial co-mingled scenarios, so as to determine the least $\mathrm{CO}_{2} \mathrm{e}$ emission-intensive option.

This study considered GHG emissions due to three different types of collection systems. i) Kerbside sort or source segregation, wherein materials are separated at the kerbside and placed into different compartments of the collection vehicles (Baird et al., 2013). ii) Single stream or full co-mingling, wherein materials are collected and compacted together. They are later separated at the Materials Recovery Facility (Waste and Resource Action Programme, 2014a). iii) Two streams or partial co-mingling, where residents place materials in two different containers, usually paper/card in one container and plastic, glass, and metals in the other (Waste and Resource Action Programme, 2014a).

\section{Materials and Methods}

Municipalities in the UK regularly review their waste management practices and options so as to mitigate the environment impact of MSW. It is important that such reviews also consider emissions associated with waste collection practices inherent to specific waste management options. This study used a combination of approaches to evaluate the $\mathrm{CO}_{2} \mathrm{e}$ emissions and savings of waste management activities, namely the GHG Calculator (Greater London Authority, 2014a) and Emissions Tool (Department of Energy and Climate Change, 2014). The GHG calculator was used to estimate emissions arising from municipal waste management operations, including transportation from the transfer stations to further treatment locations. The GHG Calculator, however, could not be used for estimating emissions arising from waste collection due to unavailability of vehiclespecific distances. As a result, Emission Tool was used to estimate the waste collection related emissions (see Section 2.2).

The study was conducted with waste management data from RBK (London, UK). The size of RBK is $37.24 \mathrm{~km}^{2}$ (London Councils, 2013), and its population as of 2013 was 166,793 (GeoWise, 2013). At RBK, residents separate their waste into four different categories: recyclable materials, cardboard, food waste and the waste that cannot be either composted or recycled i.e. waste destined for landfilling (The Royal Borough of Kingston upon Thames, 2014a). Garden waste is collected separately by subscription or purchase of garden bags (The Royal Borough of Kingston upon Thames, 2014b). RBK practices a source segregated collection of the recyclable waste, wherein the collection crew sorts the recyclable materials at the kerbside.

The GHG emissions and savings were calculated for the entire waste management system. For this, transportation operations and activities at intermediate and final treatment facilities were considered. After collection, the waste is sent to intermediate facilities where it is prepared for further treatments and final disposal destinations. The intermediate facilities considered were: bulking stations, material recovery facilities (MRF) and transfer stations. In addition, the following RBK waste treatments were considered: landfilling, incineration, anaerobic digestion (AD), invessel composting (IVC) and recycling.

\subsection{Data collection}

The waste data considered here was entirely the household MSW, which included recyclables, organic waste, and residual quantities for the year 2012 study period (Table 1). The residual category corresponds to all waste that is not treated, either by recycling, composting, or $\mathrm{AD}$. It should be noted that some recyclable and compostable waste has to be sacrificed to residual treatments (incineration and land-filling) due to being contaminated or mixed up with waste destined as residual (Table 1). 
Table 1: Waste types and their tonnages as used in the GHG calculator. The calculator considers the various waste categories for the emission estimates, using waste, operation and treatment-specific emission factors (Greater London Authority, 2014a; WRATE, 2011)

\begin{tabular}{|c|c|c|c|c|}
\hline MSW & Recycling & Organic & Residual & Tonnes \\
\hline Paper and Card (paper, card, cardboard) & $\sqrt{ }$ & & $\sqrt{ }$ & 9236 \\
\hline Non-recyclable paper (books) & & & $\sqrt{ }$ & 650 \\
\hline $\begin{array}{l}\text { Dense plastic (plastic rigid, bottles, video } \\
\text { tapes) }\end{array}$ & $\sqrt{ }$ & & $\sqrt{ }$ & 3555 \\
\hline Textile and shoes & $\sqrt{ }$ & & $\sqrt{ }$ & 765 \\
\hline $\begin{array}{l}\text { Miscellaneous combustible (carpet, } \\
\text { mattresses, tires, wood) }\end{array}$ & $\sqrt{ }$ & & $\sqrt{ }$ & 8708 \\
\hline $\begin{array}{l}\text { Miscellaneous non-combustible (bikes, } \\
\text { plasterboard, rubble) }\end{array}$ & $\sqrt{ }$ & & $\sqrt{ }$ & 8112 \\
\hline Glass (glass and glass mixed) & $\sqrt{ }$ & & $\sqrt{ }$ & 3751 \\
\hline Ferrous metal & $\sqrt{ }$ & & $\sqrt{ }$ & 2110 \\
\hline Non-ferrous metal and cans & $\sqrt{ }$ & & $\sqrt{ }$ & 360 \\
\hline Kitchen organic waste & & $\sqrt{ }$ & $\sqrt{ }$ & 9112 \\
\hline Garden organic/green waste & & $\sqrt{ }$ & $\sqrt{ }$ & 11585 \\
\hline $\begin{array}{l}\text { Electrical (all waste electrical and electronic } \\
\text { equipment) }\end{array}$ & & & $\sqrt{ }$ & 2428 \\
\hline Construction and demolition & $\sqrt{ }$ & & $\sqrt{ }$ & 62 \\
\hline $\begin{array}{l}\text { Fines (miscellaneous small } \\
\text { particles/fragments/objects) }\end{array}$ & & & $\sqrt{ }$ & 312 \\
\hline
\end{tabular}

Waste Treatment: The waste treatments considered were intermediate operations, recycling, organic and residual treatments. The waste quantities treated were inputted in the GHG calculator in tonnes in respective categories. The processes actually involved in each waste treatment were considered. They were intermediate operations at bulking stations and MRFs, recycling reprocessing operations, organic treatments of IVC and AD, and residual treatments such as landfill and incineration, with their specific emission factors (WRATE, 2011). The GHG Calculator has modules specific to each waste management operation and treatment, with respective emission factors as shown in Equation 2.

Waste Transport: Information about the types of vehicles used in the source segregation waste collection method and further transportation were obtained from RBK. This information included the distances travelled by each vehicle from the transfer stations to further treatment locations. However, it did not include the distance travelled for waste collection purposes. The transport vehicles used for kerbside collection were refuse collection vehicles, RCV (diesel) and kerbside sort vehicles, and the vehicles used for transportation from the transfer stations were roll on-off and artic vehicles.

Data for the waste collection distance travelled were obtained from RBK's current contractor, Veolia Environmental Services. This information included the total $\mathrm{km}$ travelled for collection purposes in 2013. Although the total $\mathrm{km}$ travelled for waste collection purposes were available, the breakdown of how many km each vehicle type travelled was not available. Without a vehicle-specific distance breakdown, it was not possible to estimate the $\mathrm{CO}_{2} \mathrm{e}$ emissions with the GHG calculator, as it requires distance input for different vehicle types. Thus, the emissions associated with waste collection were calculated separately with the Emission Tool, which allows estimating the transportation emissions by calculating the carbon factor of each type of vehicle or the use of an average vehicle emission factor $\left(\mathrm{kg} \mathrm{CO}_{2} \mathrm{e} / \mathrm{km}\right)$. 


\subsection{Data Analysis}

For an overall assessment, the entire waste management stream was considered, i.e. the emissions arising from waste transportation, intermediate facilities, residual treatments and direct landfilling, and the emission savings due to recycling and organic treatments. The waste and its transportation data from transfer stations were analysed with the GHG Calculator and the collection distance data were analysed with the Emissions Tool as stated previously.

Municipal waste management - GHG emissions assessment: The GHG calculator, an Excel based tool, was used to estimate emissions arising from municipal waste management operations (Greater London Authority, 2014a, b). The GHG calculator measures environmental benefits and impacts of waste management activities (Greater London Authority, 2014b); it considers carbon dioxide, methane and nitrous oxide emissions, expressing them as $\mathrm{CO}_{2} \mathrm{e}$ emissions or savings, depending upon how the waste is managed (Greater London Authority, 2014a). There are different carbon modules in the GHG calculator; each contains information about the $\mathrm{CO}_{2} \mathrm{e}$ performance of each waste management operation/activity. Equation-1 outlines the factors the GHG calculator takes into account to calculate the net GHG emissions:

Net GHG (tonnes $\left.\mathrm{CO}_{2} \mathrm{e}\right)=$ [Vehicles $\mathrm{x}$ Carbon factor] $\mathrm{x}$ tonnes $\mathrm{x} \mathrm{km}+$ [Intermediate facilities $\mathrm{x}$ Carbon factor] $\mathrm{x}$ tonnes $-[$ (Recycling $\mathrm{x}$ Carbon factor) $\mathrm{x}$ tonnes + (Organic Treatments $\mathrm{x}$ Carbon factor) $\mathrm{x}$ tonnes] + [Landfilled waste $\mathrm{x}$ Carbon factor] $\mathrm{x}$ tonnes + [Incinerated waste $\mathrm{x}$ Carbon factor $\mathrm{x}$ tonnes]

(Equation 1)

The computation considers that each of the different categories (vehicles, treatments, etc.) have different emission factors for each subcategory, and different vehicles have different emission factors, and so do different treatments, as shown in Equation 2.

The GHG calculator uses the following computational equation:

Net GHG (tonnes $\left.\mathrm{CO}_{2} \mathbf{e}\right)=[0.00142($ Kerbside sort $(\mathrm{KS})$ caged light commercial vehicle (LCV) $)+$ 0.00034 (Artic) +0.00024 (Roll on-off) +0.00027 (RCV Diesel) $] \mathrm{x}$ tonnes x km $+[0.0036$ (Bulking Station) $+0.0088($ HRRC $)+0.0195($ MRF $)] x$ tonnes $-[10.72$ (Non-Ferrous) +1.62 (Ferrous) + 0.30 (Paper) +0.06 (Card) + 4.37 (Textile) +0.23 (Glass-Mixed) +0.92 (Dense Plastic) +0.64 (Film Plastic)] $\mathrm{x}$ tonnes $-[0.04$ (AD Biogen Greenfinch) +0.04 (IVC Agrivert) $] \mathrm{x}$ tonnes $+[0.51$ (Paper) +0.51 (Non-recyclable paper) +0.01 (Dense Plastic) +0.001 (Plastic Film) +0.27 (Textile) +0.46 (Miscellaneous combustible) +0.0006 (Miscellaneous non-combustible) +0.00 (Glass) +0.00 (Ferrous Metal) +0.001 (Non-ferrous metal) +0.37 (Kitchen organic waste) +0.37 (Garden organic waste) +0.02 (Electrical) +0.01 (Potentially Hazardous) +0.34 (Fines) $\mathrm{x}$ tonnes (Landfilled) $+0.005 \times$ tonnes (Incineration)

(Equation 2)

As is clear from the computation, it takes into account the vehicles types, operations at intermediate facilities, savings due to recycling, $\mathrm{AD}$ and composting, emissions due to landfilling for each waste type, and emission arising from waste incineration; thus it allows the estimation of net GHG emissions from the entire waste management system (Equation 2). The emission factors used in GHG computation are derived from the Waste and Resources Assessment Tool (WRATE) version 2 and the Department of Energy and Climate Change (DECC) data (Greater London Authority, 2014a). 
Local waste collection emissions: The waste collection related emissions were calculated using the Emission Tool (ET), which considers the carbon emission factors of different vehicles as used (Table 2). With this, the $\mathrm{CO}_{2} \mathrm{e}$ of the transportation fleet was evaluated. The ET was created in 2009 by Atomic Energy Authority (AEA) Energy and Environment, on behalf of DEFRA. It uses data from the Carbon Trust's Baseline and Forecasting as well as the Value at Stake (VAS) tool (Department of Energy and Climate Change, 2014).

Table 2: Carbon factors used in the assessment of GHG emissions from transportation associated with local waste collection

\begin{tabular}{ll}
\hline Vehicle type/capacity & $\mathrm{kg} \mathrm{CO}_{2} \mathrm{e} / \mathrm{km}^{*}$ \\
\hline HGV Rigid $>3.5-7.5 \mathrm{t}$ & 0.56 \\
HGV Rigid $>7.5-17 \mathrm{t}$ & 0.75 \\
HGV Rigid $>17 \mathrm{t}$ & 0.97 \\
\hline
\end{tabular}

HGV: heavy goods vehicle. *Estimated using the Emissions Tool

The vehicles were classified by fuel type and size. The amount $(\mathrm{kg})$ of $\mathrm{CO}_{2} \mathrm{e}$ emissions per $\mathrm{km}$ travelled were calculated by taking into account each vehicle's $\mathrm{CO}_{2} \mathrm{e}$ factor (Table 2) and averaging these emissions across all vehicles to obtain an average emission factor for the vehicles used. This average emission factor $\left(\mathrm{kg} \mathrm{CO}_{2} \mathrm{e}\right.$ per $\left.\mathrm{km}\right)$ was then multiplied by the total $\mathrm{km}$ travelled for waste collection by all vehicles, since the information about each vehicle's distance travelled was not available. With this tool, the carbon footprint of RBK's current source segregation and proposed partial co-mingling fleets were calculated. Due to unavailability of information on vehicle type i.e. design and capacity, etc. suitable for a fully-co-mingled waste collection fleet, this option was not considered in the waste transport emission estimations.

\subsection{Carbon footprint estimation}

The data were sorted according to waste categories (Table 1). This also required MSW compositions and destinations for recycling, residual and organic waste. The composition of MSW was obtained by adding the composition tonnage of kerbside collected waste to that brought by RBK residents to the household reuse and recycling centre (HRRC).

For the organic treatments, the green and food waste categories were considered. This included green organic material and kitchen/food waste from both kerbside collection and HRRC. The residual waste section of the GHG calculator was completed with the total tonnage from kerbside, HRRC and other waste arising (street sweepings, etc.). The GHG calculator considers the tonnages entered for the reprocessing or disposal treatments (landfill, incineration, composting, $\mathrm{AD}$, and recycling) and gives an estimate of the total GHG emitted.

\subsection{Comingling emission projections}

Based on the current waste collection figures, co-mingling scenarios were modelled. For full co-mingling, non-ferrous, ferrous, paper, cardboard, textile, plastic and glass were added together. For partial comingling, non-ferrous, ferrous, plastic and glass wastes were added together, while paper, cardboard and textile were considered separately.

\section{Results and Discussion}

This study analysed the $\mathrm{CO}_{2} \mathrm{e}$ savings and emissions to better understand the environmental consequences of the waste collections and disposal treatments. Data from RBK's current waste management system (source segregation) were collected and analysed to determine its carbon footprint. The full and partial co-mingling scenarios as possible future waste management options were modelled, using data from the current 
source segregation system. The analysis considered the GHG emissions from waste transportation, intermediate facilities, treatments (incineration, landfill, AD and IVC), and GHG savings from recycling and organic treatments.

\subsection{GHG emissions from waste transportation}

The estimation of emissions from transport operations was worked out by computing emissions from local waste collection and its further transportation. Together they represent emissions arising from all waste transport operations. For the collection part of waste two different collection fleets were compared. The fleets examined were RBK's actual source segregation fleet, and one that would suit the proposed partial co-mingled option. Due to non-availability of information on transport fleet that would suit a full comingled option, it was not possible to determine transport emissions arising from this option.

Table 3: Total transportation emissions by collection and transportation from transfer stations*

\begin{tabular}{lcccccc}
\hline & \multicolumn{2}{c|}{ Waste Collection } & \multicolumn{2}{c}{ From Transfer Stations } & \multicolumn{2}{c}{ Total Transport } \\
\cline { 2 - 7 } & $\mathrm{SS}$ & $\mathrm{PC}$ & $\mathrm{SS}$ & $\mathrm{PC}$ & $\mathrm{SS}$ & PC \\
\hline $\mathrm{t} \mathrm{CO}$ & 0.204 & 0.19 & 0.0225 & 0.0228 & 0.227 & 0.212 \\
$\mathrm{t} \mathrm{CO}$ - $\mathrm{CO}_{2} \mathrm{e}$ total & 12821 & 11888 & 1413 & 1435 & 14234 & 13323 \\
\hline
\end{tabular}

SS: Source Segregation, PC: Partial Co-mingling. *The estimates are based on the current

requirement of 34 vehicles (source segregation), which will reduce to 25 vehicles for the partial comingled option.

The total transportation emissions for both source segregation and partial co-mingled waste management options are shown in Table 3. This resulted in 14,234 tonnes $\mathrm{CO}_{2} \mathrm{e}$ emitted for the source segregation and 13,323 tonnes $\mathrm{CO}_{2}$ e for the partial co-mingling collection fleet. The distance travelled in the collection operations was 543,942.2 $\mathrm{km} /$ year for the current source segregation fleet; the partial co-mingling scenario was modelled assuming the same distance travelled. The actual waste collection distance in the partial co-mingling scenario, however may be different compared to the currently operative system of waste collection i.e. source segregation. The source segregation fleet consists of 34 vehicles, while the partial co-mingling fleet consists of 25 vehicles. This resulted in fewer carbon emissions for the partial co-mingling scenario. The source segregation fleet emits 0.227 tonnes $\mathrm{CO}_{2} \mathrm{e}$ / tonne of waste and the partial co-mingling fleet emits 0.212 tonnes $\mathrm{CO}_{2} \mathrm{e} /$ tonne waste. Nonetheless, a key point is that the collection part of waste transport is responsible for majority of the emissions (Table 3 ).

\subsection{GHG emissions from Intermediate Facilities}

The operations at intermediate facilities include sorting at the MRF, placing similar materials together at the bulking stations and transfer of solid waste from collection vehicles into larger ones for further destinations. This amounted to 506 tonnes of $\mathrm{CO}_{2} \mathrm{e}$ emitted for source segregation, 531 tonnes $\mathrm{CO}_{2} \mathrm{e}$ for partial co-mingling and 566 tonnes $\mathrm{CO}_{2} \mathrm{e}$ for full co-mingling waste collection methods (Table 4). The $\mathrm{CO}_{2} \mathrm{e}$ emissions from full and partial co-mingling are higher than source segregation. Full co-mingling represents the highest intermediate facilities emissions. A possible reason for this is that waste is placed in one container and collected in a single compartment of a vehicle; this requires more energy to later separate the different materials at the sorting stations (Fitzgerald et al., 2012). Similarly, in partial co-mingling waste is collected in two compartments of a vehicle, thus requiring greater energy at waste sorting stations than multiple smaller containers as in source segregation method of waste collection. 
Table 4: Total emissions from the intermediate facility operations for the three waste collection types

\begin{tabular}{cccc}
\hline & \multicolumn{3}{c}{ Intermediate Facility } \\
\hline & SS & PC & FC \\
\cline { 2 - 4 } Tonnes of waste & 60,745 & 60,745 & 60,745 \\
t CO 2 e/t waste & 0.0083 & 0.0087 & 0.0093 \\
t CO 2 e total & 506 & 531 & 566 \\
\hline
\end{tabular}

SS: Source Segregation, FC: Full Co-mingle, PC: Partial Co-mingle.

\subsection{GHG savings from recycling}

The $\mathrm{CO}_{2} \mathrm{e}$ savings are expressed as negative tonnes. The results from the recycling savings were $-5,897$ tonnes $\mathrm{CO}_{2} \mathrm{e}$ for source segregation $\left(-0.0940\right.$ tonnes $\mathrm{CO}_{2} \mathrm{e} /$ tonne waste), $-6,524$ tonnes $\mathrm{CO}_{2} \mathrm{e}\left(-0.1040\right.$ tonnes $\mathrm{CO}_{2} \mathrm{e}$ /tonne waste) for full co-mingling and 5,581 tonnes $\mathrm{CO}_{2} \mathrm{e}\left(-0.0890\right.$ tonnes $\mathrm{CO}_{2} \mathrm{e}$ /tonne waste) for partial co-mingling. This amounts to an average of $9.61 \%$ more $\mathrm{CO}_{2} \mathrm{e}$ savings in full co-mingling than source segregation, and $14.45 \%$ more $\mathrm{CO}_{2} \mathrm{e}$ savings in full co-mingling than partial co-mingling. Another study that compared full and partial co-mingling waste collection approaches, also showed higher $\mathrm{CO}_{2}$ e savings for full co-mingling; the reason for this was that full comingling resulted in higher collection rates than partial co-mingling (Fitzgerald et al., 2012). It should be noted that the co-mingling scenarios in this study are projections, and the exact waste tonnages being recycled could not be predicted for these options. Because of this, the projections were calculated using the same waste quantities recycled from the actual source-segregation scenario under co-mingling circumstances. The differences seen in carbon savings across the three options (source segregation, partial- and full-comingled) are due to their default emission factors in the GHG Calculator. Nonetheless, this might represent an overestimation or underestimation of the recycling savings in the partial and full co-mingling scenarios, depending on the actual amounts of waste recycled.

\subsection{GHG emissions from treatments}

The various treatments considered include land-filling, incineration, and organic treatments (AD and IVC combined); their respective tonnage is as shown in Figure 1. For this, $\mathrm{CO}_{2} \mathrm{e}$ emissions and savings of the disposal treatments were considered; the emissions arise from land-filling and incineration treatments, while savings are made by organic waste (food and garden waste) treatments. Waste land-filling resulted in the emission of 1,966 tonnes $\mathrm{CO}_{2} \mathrm{e}$ for source segregation, 1,869 tonnes $\mathrm{CO}_{2} \mathrm{e}$ for full comingling and 1,967 tonnes $\mathrm{CO}_{2} \mathrm{e}$ for partial co-mingling (Table 5). Waste incineration (without energy recovery) resulted in 2,409 tonnes $\mathrm{CO}_{2} \mathrm{e}$ emitted for source segregation, 2,429 tonnes $\mathrm{CO}_{2} \mathrm{e}$ for full co-mingling and 2,538 tonnes $\mathrm{CO}_{2} \mathrm{e}$ for partial co-mingling. It is rather questionable as to why the same amount of waste when incinerated or landfilled should have different emissions, albeit slightly, for the three waste collection options (SS, PC and FC - see Table 5). This is a limitation in the GHG calculator that it considers certain default waste percentages (of the total waste composition) for different treatments under FC and PC waste collection methods and does not allow inputting the actual percentages of waste recycling, land filling or incineration, for example. This may be possibly reflective of the inherent differences in the amount of waste that would be collected for land-filling, incineration or recycling under these waste collection methods (SS, PC and FC). For example, the textile percentage for partial co-mingled option is set at $2 \%$, while that for full co-mingled is set at $0 \%$ (although the total textile tonnes entered by the user is the same). In practice, the composition of waste under SS, PC and FC can be significantly different compared to these default values. Clearly this is a weakness in the GHG Calculator. Nonetheless, organic treatment 
resulted in savings of -871 tonnes $\mathrm{CO}_{2} \mathrm{e}$. In this case, the organic treatment results were the same for the three collection types, because food and garden waste are collected separately (Table 5) and hence choice of MSW collection (SS, PC or FC) would have no bearing on carbon emissions/savings.

Table 5: The total $\mathrm{CO}_{2} \mathrm{e}$ emissions from each of the treatments considered

\begin{tabular}{|c|c|c|c|c|c|c|c|c|}
\hline \multirow{2}{*}{ (n) } & \multicolumn{3}{|c|}{ Incineration } & \multicolumn{3}{|c|}{ Landfill } & \multicolumn{2}{|c|}{ Organic Treatments } \\
\hline & SS & $\mathrm{PC}$ & FC & SS & & FC & SS & $\mathrm{PC}$ \\
\hline Waste tonnage $(\mathrm{t})$ & & 22735 & & & 8974 & & & 9829 \\
\hline $\mathrm{tCO}_{2}$ & 0.106 & 0.111 & 0.107 & 0.219 & 0.219 & 0.208 & & -0.088 \\
\hline $\mathrm{t} \mathrm{CO}_{2} \mathrm{e} /$ total waste & 2409 & 2538 & 2429 & 1966 & 1967 & 1869 & & -871 \\
\hline
\end{tabular}

SS: Source Segregation, FC: Full Co-mingle, PC: Partial Co-mingle

Total waste: 60,745 tonnes

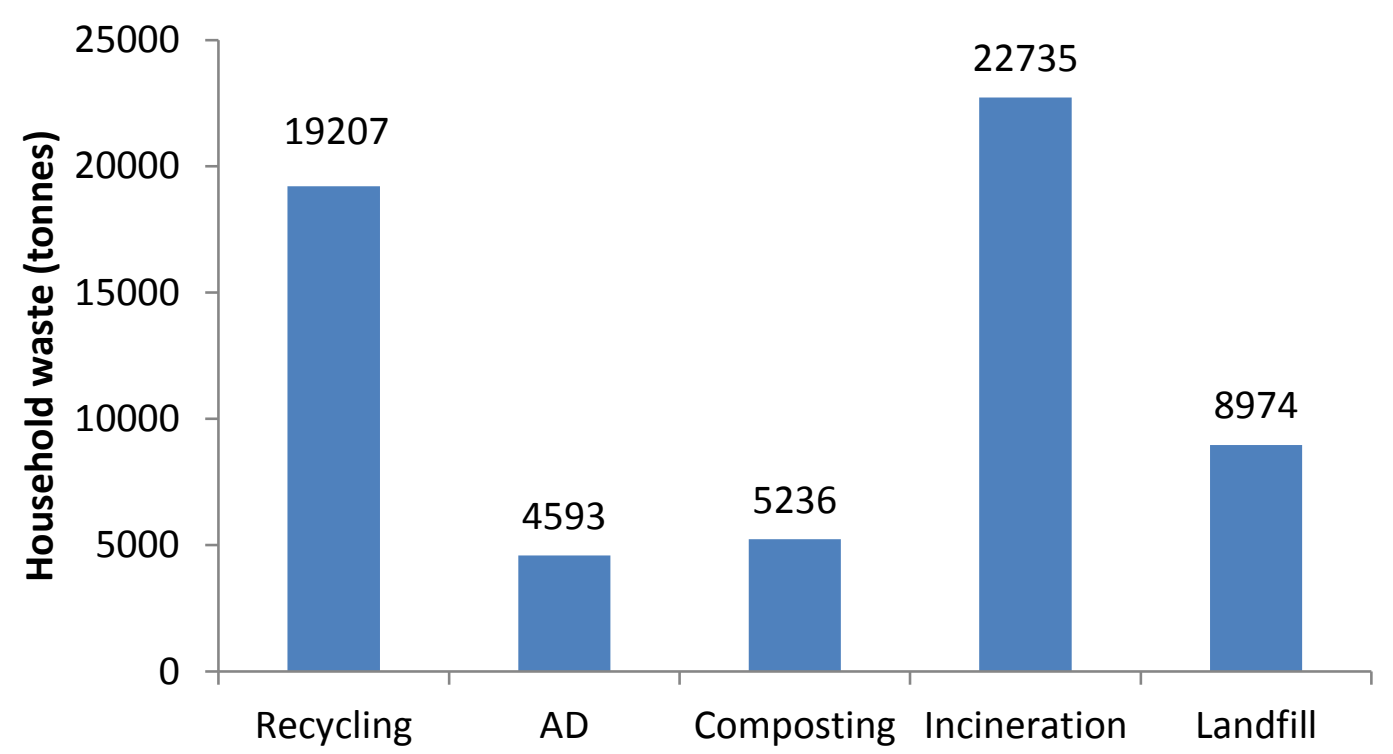

Figure 1: Tonnage of household waste treated under different waste treatment options for the year 2012

\subsection{Total GHG emissions}

The total GHG emissions were calculated by considering emissions/savings resulting from the waste treatments and operations used at RBK in 2012 for source segregation, partial and full co-mingling scenarios. Figure 2 represents a comparison of the emissions associated with different waste management operations/treatments for the three waste collection options. 


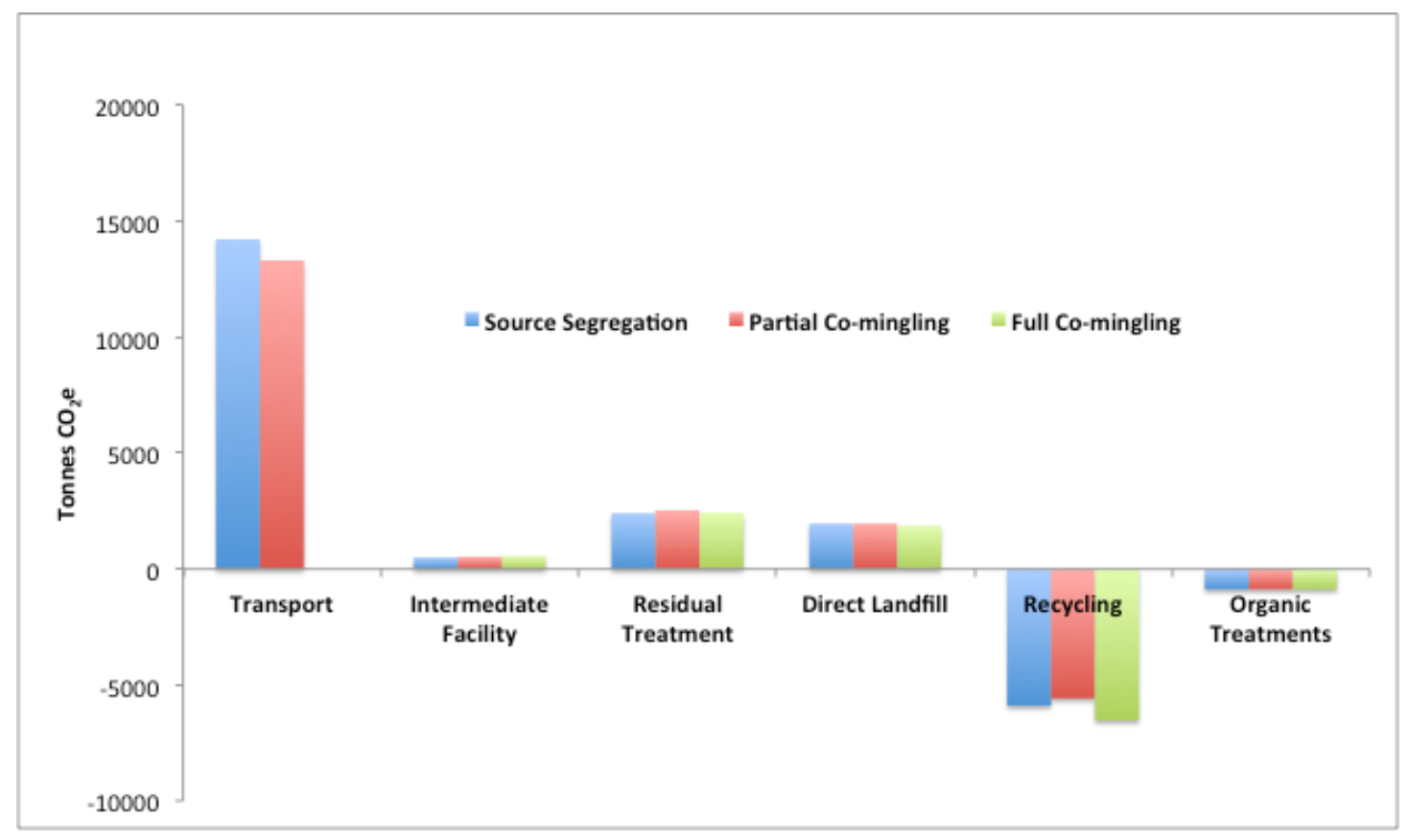

Figure 2: The $\mathrm{CO}_{2} \mathrm{e}$ emissions and savings ( $\left(\mathrm{CO}_{2} \mathrm{e}\right)$ from transport, intermediate facilities, residual treatment, landfill, recycling and organic treatments for the year 2012. The graph shows the carbon performance results for source segregation, partial and full co-mingling scenarios. Note that transport emissions for the full co-mingling scenario were not estimated due to unavailability of suitable fleet.

For the transportation emission, partial co-mingling represents slightly lower $\mathrm{CO}_{2} \mathrm{e}$ emissions than source segregation (Figure 2). A change in the fleet's vehicle types and a reduction in the number of vehicles resulted in the reduction of $\mathrm{CO}_{2} \mathrm{e}$ emissions in the partial co-mingling transport scenario. The total transport emissions were estimated for source segregation and partial co-mingling, as information on full-comingling fleet was not available.

The results from the various operations and treatments were combined together to assess an overall performance of the waste management options considered, i.e. source segregation and partial co-mingling. The findings show that both waste management systems presented net $\mathrm{CO}_{2} \mathrm{e}$ emissions. The net $\mathrm{CO}_{2} \mathrm{e}$ contribution of all the processes considered resulted in 12,347 tonnes $\mathrm{CO}_{2} \mathrm{e}$ emitted for the source segregation scenario and 11,907 tonnes $\mathrm{CO}_{2} \mathrm{e}$ for the partial co-mingled option). This equates to $203.26 \mathrm{~kg} \mathrm{CO}_{2} \mathrm{e} /$ tonne and $196.02 \mathrm{~kg} \mathrm{CO}_{2} \mathrm{e} /$ tonne for the source segregation and partial co-mingling options, respectively. The change from a source segregation fleet to a partial co-mingling fleet reduces the net $\mathrm{CO}_{2} \mathrm{e}$ emitted, at least partly due to a change in the number and type of vehicles.

It should be noted that our estimations are based on the assumption that a shift from a source-segregation to a partial or full co-mingled system has no effect on waste treatment processes e.g. recycling, composting or incineration. Such a shift, in practice, however, can potentially change the amount of waste for these processes and hence GHG emissions.

\subsection{RBK and National Data}

The results obtained from RBK's current (source segregation) and proposed (partial comingling) waste management options were compared with the England waste management data (Table 6). The comparison is based on the 2012 data for both RBK and England (Government UK, 2014a). The total national (England) GHG emissions 
from waste management activities are based on those reported by Mühle et al. (2010).

Table 6: A comparison of RBK waste management performance with England for the year 2012

\begin{tabular}{ccc} 
& England $¥$ & RBK§ \\
\cline { 2 - 3 } Recycling & $43.2 \%$ & $47 \%$ \\
Landfill & $34 \%$ & $15 \%$ \\
$\begin{array}{c}\text { Incineration with energy recovery } \\
\text { (England) and without (RBK) }\end{array}$ & $22 \%$ & $38 \%$ \\
$\quad \begin{array}{c}\text { Total GHG per tonne of waste } \\
\text { (kg/tonne) }\end{array}$ & 175 & $196(203)^{*}$ \\
$\begin{array}{c}\text { Total GHG per total waste (tonnes } \\
\text { CO }\end{array}$ & $3,955,000$ & $11,907(12,347)^{*}$ \\
\hline
\end{tabular}

$¥$ Source: Mühle et al. (2010)

$\S$ For RBK, the total GHG emissions do not include energy recovery from waste incineration.

*Total GHG emission figures of $196 \mathrm{~kg} \mathrm{CO} \mathrm{CO}_{2} \mathrm{e} / \mathrm{t}$ and $11,907 \mathrm{t} \mathrm{CO}_{2} \mathrm{e}$ ) are for the proposed partial comingling model and those marked with asterisk $\left({ }^{*}\right)$ are for the currently operative source segregation approach

The total GHG quantities calculated for RBK are in range with the data published for England. The main reasons for municipalities to continue diverting the waste sent to landfill are the Landfill Tax, and the goal to achieve a 50\% recycling rate by 2020 (Government UK, 2014b). Despite greater recycling and lower waste land-filling, RBK estimates show greater emissions per tonne waste generated as compared to national figures (Table 6). It should be noted that the GHG calculator considered incineration without energy recovery for RBK, because sufficiently robust data on energy parameters was not available. It is thus quite likely that the actual RBK emissions for the partial comingling option (196 $\mathrm{kg} \mathrm{CO} \mathrm{CO}_{2} \mathrm{e} /$ tonne waste) could be similar to that of national average (175 $\mathrm{kg} \mathrm{CO}_{2} \mathrm{e} /$ tonne waste) when energy recovery from waste incineration for RBK is considered.

\section{Conclusion}

This study estimated $\mathrm{CO}_{2} \mathrm{e}$ emissions of the waste management operations at $\mathrm{RBK}$, which amounted to $196 \mathrm{~kg} \mathrm{CO} 2 \mathrm{e} / \mathrm{t}$ (partial comingling) and $203 \mathrm{~kg} \mathrm{CO} \mathrm{CO}_{2} \mathrm{e} / \mathrm{t}$ (source segregation) for the waste collected in 2012; these figures are somewhat higher but are within range with the national average. Furthermore, the RBK emissions are without energy recovery while the national average emissions are based on energy recovery from waste incineration. Here we could not estimate energy recovery because of insufficient information on the energy parameters. Of the treatments evaluated, the GHG estimated for landfill represents the highest $\mathrm{CO}_{2} \mathrm{e}$ emissions, while recycling represents the highest $\mathrm{CO}_{2} \mathrm{e}$ savings. With the much higher recycling targets, the emissions from land-filling are expected to decrease with time.

The $\mathrm{CO}_{2} \mathrm{e}$ savings from source segregation are higher than partial co-mingling when transport emissions are not considered. However, when the transportation emissions included, changing from the source segregation to the partial co-mingling option fleet could save up to 440 tonnes of $\mathrm{CO}_{2}$ e per year (3.56\% reduction).

The GHG model is based on set definitions, and it is used to make broad estimations. The GHG calculator offers seven different collection composition scenarios that complete the recycling module, for example. We chose what resembles full and 
partial co-mingling best). That translates them into default percentages for different waste categories when choosing the waste collection method, not allowing the input of actual figures for those waste categories. Also, it does not take into consideration technological advances of waste management through the years. In other words, the practical aspect of waste management does not easily fit into a theoretical model, although it does allow broad estimations of emissions. The findings observed would benefit from further research with more advanced carbon footprint calculators.

\section{Acknowledgements}

We thank the Royal Borough of Kingston for providing the waste management data and taking interest in considering carbon emissions from their waste management options and operations.

\section{References}

Baird J, Curry R and Reid T (2013) Development and application of a multiple linear regression model to consider the impact of weekly waste container capacity on the yield from kerbside recycling programmes in Scotland. Waste Management and Research 31: 306-314.

Department of Energy and Climate Change (2014) NI 185 Emissions Tool: http://www.decc.gov.uk/assets/decc/Statistics/nationalindicators/ni185emissio nstool.xls (accessed 20 July 2014).

Eisted R, Larsen AW and Christensen TH (2009) Collection, transfer and transport of waste: accounting of greenhouse gases and global warming contribution. Waste Management and Research 27: 738-745.

Eurostat (2012) Environment in the EU27: http://epp.eurostat.ec.europa.eu/cache/ITY PUBLIC/8-27032012-AP/EN/827032012-AP-EN.PDF (accessed: 22 March 2014).

Fitzgerald GC, Krones JS and Themelis NJ (2012) Greenhouse gas impact of dual stream and single stream collection and separation of recyclables. Resources, Conservation and Recycling 69: 50-56.

GeoWise (2013) Kingston Data: http://data.kingston.gov.uk/dataviews/tabular?viewId=332\&geoId=4\&subsetId= $\underline{11}$ (accessed 16 July 2014).

Government UK (2014a) Statistics on waste managed by local authorities in England in 2012/13:

https://www.gov.uk/government/uploads/system/uploads/attachment data/fil e/255610/Statistics Notice1.pdf (accessed 19 June 2014).

Government UK (2014b) Waste legislation and regulations: https://www.gov.uk/wastelegislation-and-regulations (accessed 15 March 2014).

Greater London Authority (2014a) Greenhouse Gas Calculator for Municipal Waste User Manual:

http://www.london.gov.uk/sites/default/files/archives/GreenhouseGasCalcUser Manual.pdf (accessed: 2 May 2014).

Greater London Authority (2014b) Appendix 4b: Development of a $\mathrm{CO}_{2}$ eq emissions performance standard for the management of London's municipal waste: http://www.london.gov.uk/sites/default/files/GLA001MWS\%20APPENDIX\%204 b.pdf (accessed: 2 May 2014).

Levis JW, Barlaz MA, DeCarolis JF and Ranjithan SR (2013) A generalized multistage optimization modeling framework for life cycle assessment-based integrated solid waste management. Environmental Modelling and Software 50: 51-65.

London Councils (2013) Royal Borough of Kingston upon Thames: http://www.londoncouncils.gov.uk/services/lept/boroughmap/kingston/ (accessed 16 July 2014). 
Mühle S, Balsam I and Cheeseman CR (2010) Comparison of carbon emissions associated with municipal solid waste management in Germany and the UK. Resources, Conservation and Recycling 54: 793-801.

Papageorgiou A, Barton JR and Karagiannidis A (2009) Assessment of the greenhouse effect impact of technologies used for energy recovery from municipal waste: a case for England. Journal of Environmental Management 90: 2999-3012.

The Royal Borough of Kingston upon Thames (2014a). Your containers- A guide: http://www.kingston.gov.uk/info/200275/houses your collection service explained/690/your containers (accessed 26 June 2014).

The Royal Borough of Kingston upon Thames (2014b) Biodegradable garden bags: http://www.kingston.gov.uk/info/200277/garden waste/701/biodegradable ga rden bags - find out more (accessed: 26 June 2014).

The Royal Borough of Kingston upon Thames (2014c) Recycling Centre (Villiers Road) and neighbourhood recycling sites:

http://www.kingston.gov.uk/info/200273/waste and recycling/705/recycling_c entre villiers road and neighbourhood recycling sites (accessed: 26 June 2014).

Vergara SE and Tchobanoglous G (2012) Municipal solid waste and the environment: a global perspective. Annual Review of Environment and Resources 37: 277-309. 